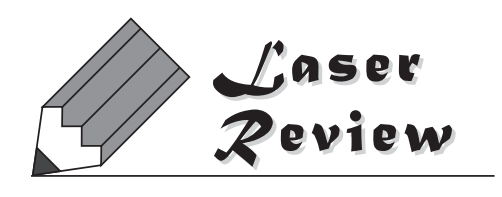

\title{
空間分割多重光増幅方路制御ノードの省電力化技術
}

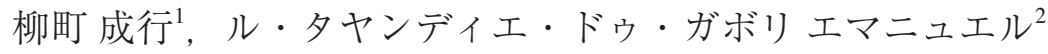 \\ ${ }^{1}$ 日本電気株式会社IoTデバイス研究所 (テ305-8501つくば市御幸が丘34) \\ ${ }^{2}$ 日本電気株式会社IoTデバイス研究所 ( $=211-8666$ 川崎市中原区下沼部1753)
}

\section{Low Power Consumption Technologies for Space-Division Multiplexing Optical Amplification and Switching Nodes}

\author{
Shigeyuki YANAGIMACHI ${ }^{1}$ and Emmanuel LE TAILLANDIER DE GABORY ${ }^{2}$ \\ ${ }^{1}$ NEC Corporation, IoT Devices Laboratories, 34 Miyukigaoka, Tsukuba 305-8501 \\ ${ }^{2}$ NEC Corporation, IoT Devices Laboratories, 1753 Shimonumabe Nakahara-ku, Kawasaki 211-8666
}

(Received March 30, 2018)

\begin{abstract}
Space-division multiplexing nodes are attracting attention for future ultra-high capacity networks; low power consumption technologies for space-division multiplexing optical amplification and switching repeater nodes are required in this context. Here, we review technologies for low power consumption of optical amplifiers, which are used for compensating the loss of fibers and optical nodes. Namely, we present recent research results and the plausible evolution regarding the module structure and high efficiency pump control technologies for multicore erbium doped fiber amplifiers.
\end{abstract}

Key Words: Space-division multiplexing, Multicore fibers, Erbium doped fiber amplifiers, Pump lasers

1.はじめに

近年, インターネットトラフィック等の増大に伴い, 光伝送では高速・大容量通信を行うため, さまざまな取 り組みがなされてきた。高速信号生成技術としては, デ ジタルコヒーレント技術を用い, 1波長当たり $100 \mathrm{Gbp} / \mathrm{s}$ 以上の高速通信技術の実用化が進められている。 また, 大容量伝送技術としては, 波長多重技術を用いて1ファ イバ当たり $10 \mathrm{Tbps}$ 級の通信が実現されているが, SMF (Single Mode Fiber)の入力パワー制限により, 今後限界 が予想されている。これを解決する技術として1つの ファイバに複数のコアを充填するMCF(Multi Core Fiber) を用いたSDM (Space Davison Multiplexing)の研究開発が 進められている。 また，交換技術としては，ネットワー クのトポロジがPoint-to-pointからRing型となり，トラ フィックを中継するフォトニックノードとしては波長分 割多重(Wavelength Division Multiplex: WDM) 信号を波長 単位で任意に挿入分岐可能なROADM (Reconfigurable Optical Add Drop Multiplexer)が広く用いられている。現 在用いられているROADMはSMFに対応した構成である が，SDMの進展に伴い，SDMに対応した大容量フォト ニックノード(SDMノード)の実現が期待される. SDM ノードの構成をFig. 1 に示す.

SDMノードは主に, 送受信器であるTPND (Transponder), 方路の切り替えを行う光スイッチ（主にWDM信号

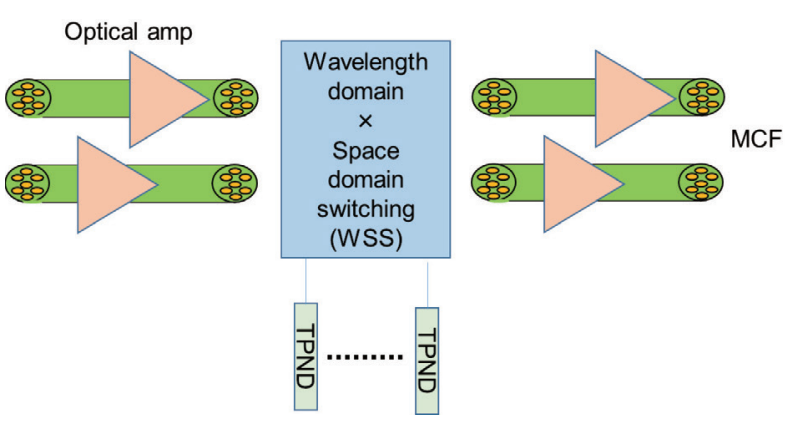

Fig. 1 Constriction of SDM Node.

を波長単位で任意に挿入分岐するWSS (Wavelength Selective Switch)が用いられている)，フォトニックノード 間で生じる光損失を補償する光アンプで構成される. SDMノードは，これまでのSMFを用いたノードに比較 して, スイッチ規模が大きくなる。すなわち, 同じファ イバ数 (入出力ポート数) で比較すると, 20 コアのMCF を用いた場合，スイッチ規模はSMFを用いた場合の 20 倍 となる。このような大規模スイッチングを有するSDM ノードは，ノードのサイズが小型であることに加えて， 省電力であることが求められるのは言うまでもない．光 アンプはノードを構成する光コンポーネントの中では, TPNDとともに電力を多く消費するコンポーネントであ るため, ノード全体の消費電力を抑えるためには, 光ア ンプの省電力化が1つのカギとなる. 本報では, 光アン 
プの省電力化に関するこれまでの取り組みを紹介すると ともに, SDMノード実現に向けた今後の期待について 述べる.

\section{MCF光増幅の省電力化技術}

\subsection{SMF用EDFAの省電力化技術}

これまで，光伝送で用いられる光アンプ技術は1本の ファイバに1つのコアを有するSMFに対応したEDFA (Erbium Doped Fiber Amplifier)を中心に研究および開発 が進められてきた。本節では，MCFの増幅技術として， MCFの各コアを光アンプ部で分離してSMFとし, EDFA で個別に励起する技術に打ける省電力化の研究開発につ いて述べる。

光アンプの省電力化を実現するには, 光増幅媒体を励 起する励起光源の消費電力をいかに低減できるかが大き なカギとなる. ここでは, 励起光源共有化技術, 励起光 リサイクル技術，動的な制御による省電力化技術につい て記述する。 まず, 励起光源共有化技術とは, 複数の励 起媒体に対して，1つの励起光源を配置して共有する方 法である。例えば，伝送媒体として12コアのMCFを用 い, 光アンプ部において，12 コアをSMFに分離後，共 有化された励起光源で励起することで省電力化が図れる ことが示されている1．ただし，1つの励起光源を用い て多数のSMFの励起を行うためには, 高出力な励起光源 が必要であるとともに, 高出力条件で高効率動作が求め られる。 すなわち, 非常に高い線形性の励起光源が必要 である。

また，高出力な励起光源の利用を避ける方法として は，励起光リサイクル技術が提案されている。 この技術 は, 複数のコアで共有する励起光源の励起光量の不足分 を, 初期に注入した励起光のうち, 励起媒体に吸収され なかった光量を光カプラ等で再度励起媒体に注入するこ とで, 従来熱として廃棄されていた光量を励起光源とし て再利用する方法である21.

また，これまで光アンプの構成やパラメー夕設定は初 期に調整された状態を維持する静的な設定がとられてい る。これに対して, 環境条件(温度等)や, トラフィック (光アンプヘの入力光量に相当)の状況に応じて動的に構 成やパラメータを変更して省電力化を図る新しい検討も なされている。具体的には, 冷却機能 (Thermoelectric Cooler: TEC) を用いた高出力励起光源と, TECを用いな い低出力励起光源を, 環境温度や光アンプヘの入力光量 に応じて，選択的に用いることにより省電力化を図る。 つまり, 入力光量が少ない場合, 低出力励起光源を用い ることにより，これまで一律に高励起光源を用いた場合 に比較して，極端な条件で $90 \%$ までの省電力化が図れる ことが報告されている゙๋ 。但し, 入力光量が大きい場合 は，省電力効果がなくなる，

さらに，これまでの励起光源共有と入力光量等に応じ た動的な制御を組み合わせた光アンプの可変共有方式も 検討されている ${ }^{4)}$. Fig. 2 に可変共有化方式の構成図, Fig. 3 に省電力効果について示す. 本検討では, 従来の

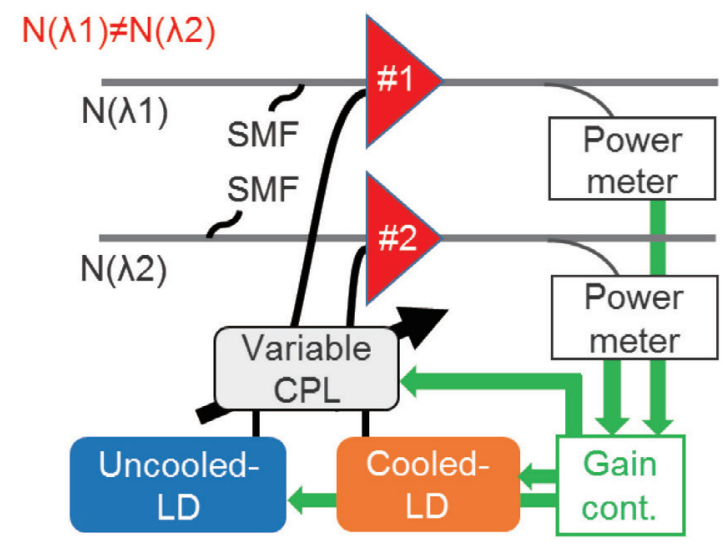

Fig. 2 Construction of variable share pumping.

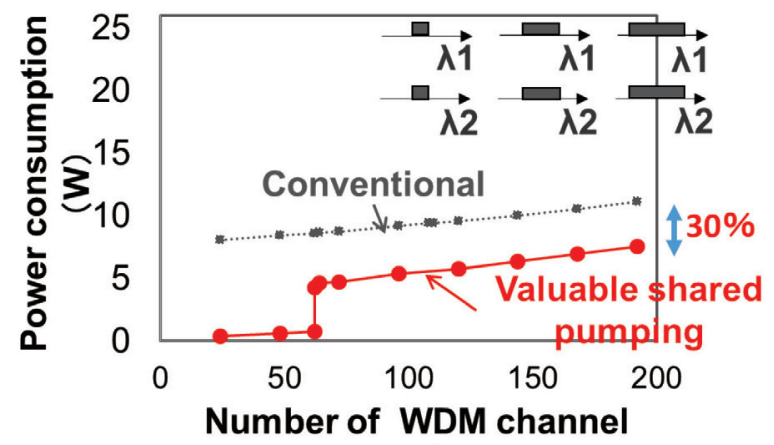

$(\lambda 1+\lambda 2)$

Fig. 3 Power reduction of variable share pumping.

SMF増幅に対して，30\%以上の電力を削減可能なことが 示されている.

\section{2 コア励起マルチコア光増幅技術}

前節では, MCFを光アンプ部でSMF化したのちに増 幅する技術について述べた。本節では，光アンプ部にお ける増幅媒体にMCFを用いて増幅を行うMC-EDFA (Multi Core EDFA) 技術のうちコア毎に増幅する技術に ついて記載する。 Fig. 4 は7 コアのコア励起MC-EDFAの 構成図である。

励起用MCFの前方および後方より $980 \mathrm{~nm}$ SM-LD (Single Mode-Laser Diode) を7つのコアに直接結合させた構 造であり，アンプ特性としては最大増幅ゲイン $15 \mathrm{~dB}$ と なっている。 なお，現在ではアンプの改善が進み増幅ゲ インも $15 \mathrm{~dB}$ 超える報告がなされている。また，開発 したアンプを用いた伝送試験では40 波長 $128 \mathrm{~Gb} / \mathrm{s}(\mathrm{PDM}-$ QPSK）信号の6160 km伝送を実現している5). しかし, 本研究で用いられているのは前節で述べたSMFの増幅技

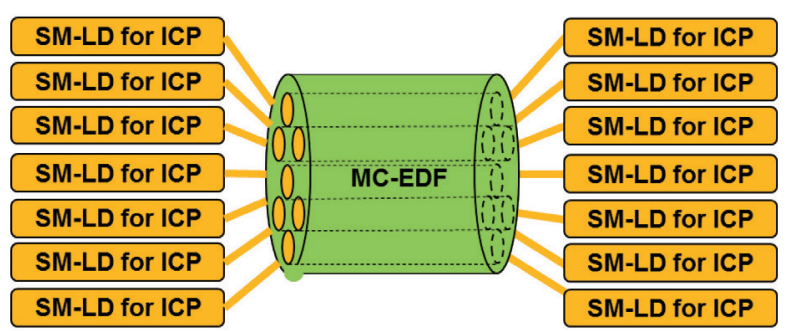

Fig. 4 Construction of MC-EDFA. 
術と同じであり, 省電力への寄与は薄い. また, 別の検 討としては, 直接的に省電力化とリンクしていないが, 結合型MCF (Coupled Core MCF) を用いた光アンプによ り，モード損失を低減する検討 $\left.{ }^{6}\right)$ や $\mathrm{MCF}$ と励起光源に MM-LD (Multi Mode Laser Diode)を用いた構成により省 電力化を図る方法が検討されている7).

\section{3 クラッド励起マルチコア光増幅技術}

これまで，MC-EDFAで検討されたコア励起に対し， 多数のコアを取り巻くクラッドをMM-LDで励起するこ とにより，複数のコアを一括励起するクラッド励起マル チコア光増幅が検討されており, これまで, 従来のSMF へEDFAを適用した場合にと比較して約 $33 \%$ 省電力効果 が報告されている ${ }^{8,9)}$ ，消費電力には， LDの変換効率と ファイバの吸収効率が寄与するが, 変換効率はクラッド 励起よりもEDFAがやや高く, 吸収効率はコア径拡大と クラッド縮小効果によりSMFよりMCFが優れている。 また, クラッド励起で用いるMM-LDは非冷却で使用で きる利点も大きく, 今後更なる低電力化が期待される.

なお, 光アンプ部において, 必要なゲインを得るには 増幅媒体の長さを十分にとる必要があるため, 利得の面 ではL帯が有利であり，当初，L帯を中心に検討がなさ れた9). しかしながら, 実際の光ネットワークは主にC 帯を中心に構成されており, 近年C帯での応用も検討さ れている10).

また，最大コア数を増大させて増幅効率を改善する方 法として，19コアのMC-EDFAを用いることで7コアの MC-EDFAに比較して, 幾何学的なクラッド対コアの密 度改善により増幅効率が高まる報告がなされている ${ }^{11)}$. さらに，32コアのMC-EDFAの開発も行われており,さ らなる増幅効率改善が見达まれる ${ }^{12)}$.

ただし，これまでの研究はMC-EDFA単体としての特 性改善についての議論であり, 各コアへの波長充填の方 法によっては, クラッド一括励起よりコア励起のほうが 増幅効率がすぐれる場合もあるため, 全体の省電力化を 図るには波長充填率も考慮する必要があると思われ る $^{13)}$.

\section{3. ハイブリッド励起による省電カマルチコア光増幅技術}

\section{1 ハイブリッド励起技術の概要}

前節で述べたクラッド励起マルチコア光増幅技術 は，1つの励起光源で複数のコアを一括に励起するため, 各コア個別に励起パワー調整することができない.この ため, これまでWDMネットワークに用いられている光 アンプには必須である自動利得制御 (Auto Gain Control: $\mathrm{AGC}$ )を個々のコアで実現することが困難である。ここ で, AGCとは入力波長数が増減しても光アンプの利得 を一定にする制御方式である。そこで，本課題を解決す ベく，クラッド励起とコア励起を併用したハイブリッド 励起技術が提案されている. Fig. 5 にハイブリッド励起 方式の構成図を示す.

ハイブリッド励起技術では, 前方励起として, $975 \mathrm{~nm}$

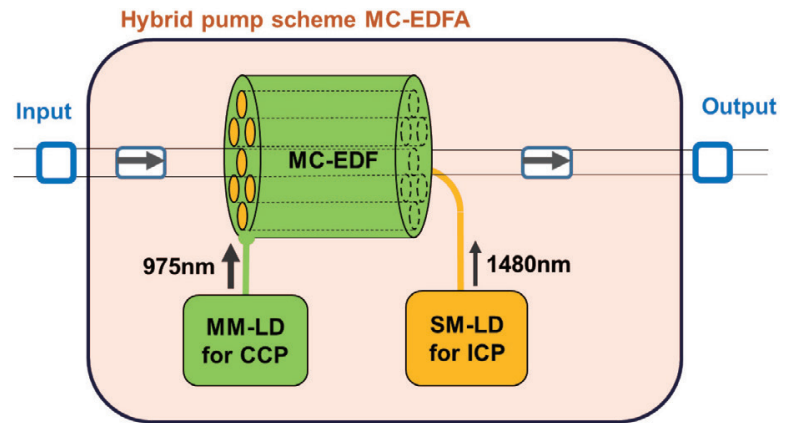

Fig. 5 Construction of Hybrid pumping. CCP: Common Clad Pumping. ICP: Individual Core Pumping.

MM-LD，後方励起として，1480 nm SM-LDを用い，入 力信号光のパワー $-6 \mathrm{~dB} \sim-21 \mathrm{~dB}$ の入力信号光パワーに 対して, 利得変化 $0.4 \mathrm{~dB}$ で制御可能なことが示されてい $ろ^{14,15)}$.

さらに，ハイブリッド励起技術を用いたシステム評価

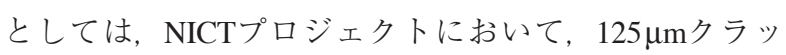
ド4コアを用いた伝送試験において, 116 波長 $36 \mathrm{Gbaud} / \mathrm{s}$ (PDM-16QAM) 信号を用いて118.5 Tbp/s $316 \mathrm{~km}$ の伝送試 験に成功している ${ }^{17)}$.

\section{2 省電力化を実現する制御技術}

本節では3.1節で挙げたハイブリッド励起方式の省電 力化制御技術について, 特に. 光アンプの動的な制御に よる省電力化に関して述べる.

3.2.1 外部温度をパラメータとした省電力化制御技術 ハイブリッド励起構成において, クラッド励起光源 を980 nm非冷却型MM-LD，コア励起光源を $1480 \mathrm{~nm}$ 冷却 型SM-LDで構成し, 動作温度によって, クラッド励起 とコア励起光源の励起パワー比率を最適化することによ り，従来の静的な条件での設定に比較して最大 $38 \%$ の電 力削減ができることが示されている18).

\subsection{2 利用コア数と伝送距離を考慮した省電力化制 御技術}

MCFは，従来のSMFに比較して芯数倍の帯域を有す る.したがって，トラフィックの状況によっては，すべ てのコアを用いない場合も多い。すなわち，利用される コア数に応じた制御による省電力化が考えられる。具体 的には, クラッド励起において, 励起光源のパワーを一 定とした場合，利用コア数が多いほどクラッド励起の配 分を大きくする制御が省電力化に効果的である。 また, 伝送距離によって必要となる光アンプのゲインも変化す るため, 伝送距離に応じた制御による省電力化も期待さ れる。具体的には，スパン長が長くなると高ゲインが必 要となるため, 高ゲインで消費電力が低いクラッド励起 が有利となり，クラッド励起の配分を大きくする制御が 省電力化に効果的である。 これを理論的，実験的に解析 (Fig. 6) し，コア励起のみの励起条件に対し，最大 $16.5 \%$ の省電力化が可能なことが示されている ${ }^{16,19)}$.

2.1節においては, SMFの省電力化技術として, 励起 


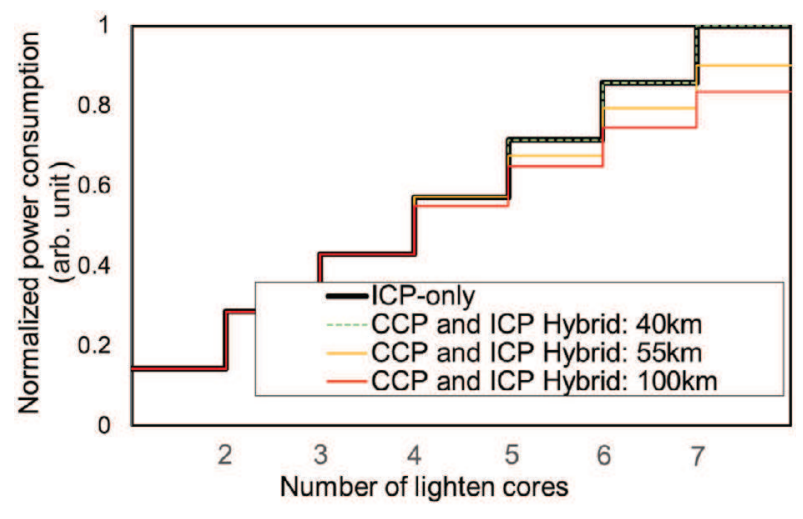

Fig. 6 Power reduction for number of using cores and transmission distance.

光源共有化技術について述べた，ハイブリッド構成にお いては, クラッド励起用MM-LD揖よびコア励起用 SM-LDがあり，制御するパラメータが増える。すすなわ ち, 増加したパラメータを最適化することにより, さら に省電力化の可能性が増大する。近年の検討では, 八イ ブリッド励起構成において, コア励起光源を7コアで共 有するとともに, その共有する比率を利用コア数に応じ て可変とすることで, コア励起のみに比較して最 大 $23.2 \%$ の省電力化が図れることが示されている ${ }^{20)}$. た だし，コア共有化では高出力で高効率が求められるた め, 共有可能なコア数は励起光源の線形性に依存する.

\section{4. 信号光パワーの平坦化技術}

本節では, WDMネットワークで必須の技術である利 得平坦化技術について述べる。従来のSMFを用いた WDMネットワークでは, 送信側TPNDから受信側TPND まで, 光スイッチ, 光フィルタ, 光アンプ等の光学素子 を複数通過するのが一般的である. この光学素子は波長 特性を持つため, 複数の送信側TPNDの光信号を均等な パワーとして波長軸方向でフラットなWDM信号を生成 しても，通過するたびに，WDM信号が波長軸方向で歪 んでしまい，信号の受信側TPNDに扔いてS/Nの劣化を 招く，そのため，例えば，ノードの出口に扔いて，1つ のコア内のWDM信号パワーを波長軸方向に执いて平坦 化することが必要である。ささらに,これまで述べた

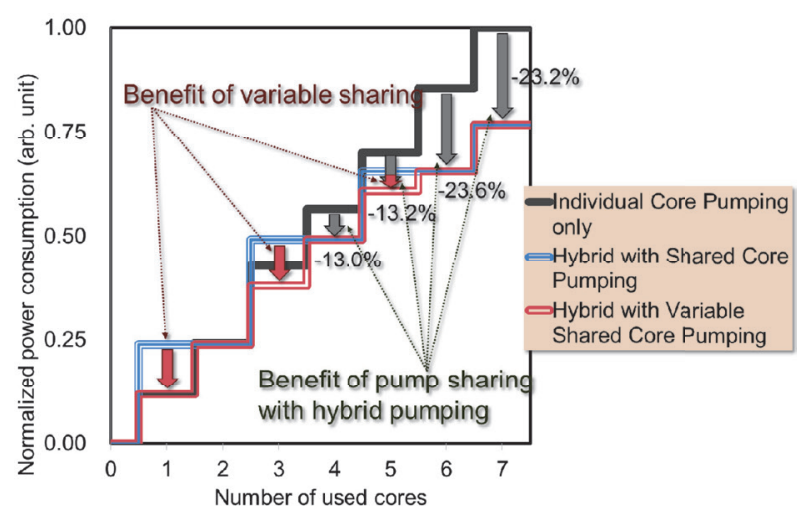

Fig. 7 Power reduction of variable share pumping.
SDMに㧍いては，MCF内に設置された複数のコア間で もパワー偏差があるため, コア間でWDM信号全体のパ ワーを平坦化する必要もある。例えば， 32 コア MCFの おいては，コア間損失ばらつきが2 $\mathrm{dB}$ 程度あることが報 告されている ${ }^{21}$.

ここで, 光アンプ自体は波長方向の平坦化制御ができ ない，このため，通常，光アンプ通過後にイコライザを 用いて平坦化するのが一般的である。しかしながら，こ の方法では, 最も低い光量の波長チャネルに合わせて, それを超える波長チャネルの光量をカットするため, 工 ネルギー効率が悪い，すなわち，なるべくこのカットす る光量を抑えつつ, 平坦化を実現することが省電力につ ながる。 この問題を解決する1つの方法として, アンプ の増幅帯域のうち, ゲインの平坦な部分を用いて波長間 のパワーばらつきを抑える方法が報告されて抢り，SMF

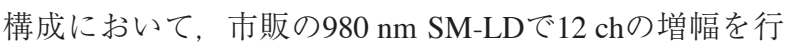
うことが可能なことが示されている1). しかしながら， 帯域を制限しているため, 伝送容量が制限されるという 問題もある。また，コア間でのパワーばらつきを平坦化 する技術としては, ハイブリッド構成に扔いて平坦化が 可能なことを示した ${ }^{14)}$. しかしながら，1つのコア内の WDM信号パワーを波長軸方向に扔いて平坦化すること ができないという問題もある.

今後, これらの問題を解決するイコライズ方法の開発 が進むことが期待される。

\section{5. スイッチとの連携による低省消費電力化技術}

これまで, 光アンプ単体での省電力化技術について記 載した，また，光ノードの省電力化技術としては，ノー ド主構成要素であるWSSの小型・省電力化の検討22) がな されており，それぞれの構成要素ごとの省電力化の検討 が進んでいる.ここでは, さらに, 光ノード内の光素子 間での連携について考察する。具体的には3.2.2節で述べ たように，利用コア数に応じて光アンプを制御すること により省電力化が図れることを示した ${ }^{16,19,20)}$. つまり， 利用コア数の変化に応じた光アンプの省電力化制御技術 とWSSの制御を連動することにより，光ノード全体と しての省電力制御の効果が高まることが期待される。例 えば，WSSの制御により，MCFの特定のコアにトラ フィックを集中させる，あるいは，すべてのコアに平均 に分散させる等の制御と, ハイブリッドMC-EDFAのク ラッド励起とコア励起の励起配分を連動させてノード全 体の消費電力を削減する等の技術が考えられ，今後の技 術検討が期待される.

\section{6. 今後の展開}

これまで, 従来のSMF，これから大容量伝送で期待さ れるMCFに扔ける省電力化技術の方向性について記載 した，特に，マルチコアに扔いては，複数のコアを一括 励起することが可能なクラッド励起の利用が光アンプの 低消費化に大きく寄与しており, さらに, コア密度を高 
める研究 ${ }^{22}$ と連動することで, その効率も高まる.コア 密度を上げたクラッドを一括で励起するには, これまで より高効率, 高出力なMM-LDの実現が期待される。ま た， $\mathrm{SMF}$ の光アンプ省電力化制御として，励起光源の共 有について述べた。この場合も, 高効率かつ高い平坦性 を持つSM-LDが期待される。

最後に, 省電力な次世代光ノードには, これまでの光 アンプ単体の制御だけではなく, WSS等他の構成要素 と連動した制御が重要である。

\section{謝 辞}

本研究内容の一部国立研究開発法人情報通信研究機構 (NICT)の委託研究「空間多重フォトニックノード基盤技 術の研究開発」プロジェクトの成果である.

\section{参考文献}

1) A. Turukhin, O. V. Sinkin, H. G. Batshon, H. Zhang, Y. Sun, M. Mazurczyk, C. R. Davidson, and J.-X. Cai: Proc. Optical Fiber Communication Conference (OFC2016) (2016) Th4C.1.

2) A. H. Gnauck, P. J. Winzer, R. M. Jopson, and E. C. Burrows: Proc. European Conference on Optical Communication (ECOC 2016) (2016) M.2.A.1.

3) 松本恵一, 竹下仁士, 柳町成行, ル・タヤンディエ・ ドゥ・ガボリ エマニュエル：電子情報通信学会通信ソサ イエティ大会 (2017) B-10-19.

4) 松本恵一, ル・タヤンディエ・ドゥ・ガボリ エマニュエル : 電子情報通信学会総合大会 (2018) B-10-20.

5) H. Takahashi, T. Tsuritani, E. L. T. de Gabory, T. Ito, W. R. Peng, K. Igarashi, K. Takeshima, Y. Kawaguchi, I. Morita, Y. Tsuchida, et al:: Proc. European Conference on Optical Communication (ECOC 2012) (2012) Post deadline Th.3.C.3.

6) N. K. Fontaine, J. Antonio-Lopez, H. Chen, R. Ryf, D. T. Neilson, A. Schulzgen, J. C. Alvarado Zacarias, R.-J. J. Essiambre, H. Sakuma, T. Hasegawa, et al.: Proc. Optical Fiber Communication Conference (OFC2013) (2013) Post deadline, Th5D.3.

7) P. M. Krummrich and K. Petermann: Proc. Optical Fiber Communication Conference (OFC2011) (2011) OMH.5

8) Y. Mimura, Y. Tsuchida, K. Maeda, R. Miyabe, K. Aiso, H. Matsuura, and R. Sugizaki: Proc. European Conference on Opti- cal Communication (ECOC 2012) (2012) Tu4.F.1

9) Y. Tsuchida, K. Maeda, K. Watanabe, T. Saito, S. Takasaka, M. Tadakuma, R. Sugizaki, H. Ogoshi, K. Doi, H. Matsuura, et al.: Proc. IEEE Photonics Society Summer Topical (2014) p. 148.

10) Y. Tsuchida, K. Maeda, K. Watanabe, K. Takeshima, T. Sasa, T. Saito, S. Takasaka, Y. Kawaguchi, T. Tsuritani, and R. Sugizaki: Proc. European Conference on Optical Communication (ECOC 2012) (2012) M.2.A.2.

11) S. Takasaka, K. Maeda, K. Kawasaki, K. Yoshioka, H. Oshio, R. Sugizaki, Y. Kawaguchi, H. Takahashi, T. Tsuritani, and M. Shiino: Proc. European Conference on Optical Communication (ECOC 2017) (2017) Th.2.D.3.

12) S. Jain, T. Mizuno, Y. Jung, J. Hayes, G. Bai, H. Ono, K. Shibahara, Q. Kang, M. Petrovich, A. Sano, et al.: Proc. European Conference on Optical Communication (ECOC 2016) (2016) Post deadline Th.3.A.1.

13) H. Takeshita, K. Matsumoto, and E. L. T. de Gabory: Proc. Optical Fiber Communication Conference (OFC 2018) (2018) M3J.5.

14）小野浩孝, 山田誠, 細川宰, 市井健太郎, 増田 浩次, 小林壮一：電子情報通信学会, 信学技報OCS2014-116 (2014) 111.

15) M. Yamada, H. Ono, T. Hosokawa, and K. Ichii: Proc. Opto-Electronics and Communications Conference (OECC2016) (2016) WC1-2.

16) E. L. T. de Gabory, S. Nakamura, S. Yanagimachi, and J. Abe : 電子情報通信学会通信ソサイエティ大会 (2017) B-10-48.

17) T. Matsui, T. Kobayashi, H. Kawahara, E. L. T. de Gabory, T. Nagashima, T. Nakanishi, S. Saitoh, Y. Amma, K. Maeda, S. Arai, et al.: Proc. Optical Fiber Communication Conference (OFC2017) (2017) Post deadline 1.

18) E. L. T. de Gabory, K. Matsumoto, S. Fujita, S. Nakamura, S. Yanagimachi, and J. Abe: Proc. Optical Fiber Communication Conference (OFC2017) (2017) Th1C.1.

19) K. Matsumoto, S. Yanagimachi, and E. L. T. de Gabory: Proc. Technical Committee on Extremely Advanced Optical Transmission Technologies (EXAT) Symposium (2017) p. 20.

20) E. L. T. de Gabory, K. Matsumoto, S. Fujita, H. Takeshita, and S. Yanagimachi: Proc. European Conference on Optical Communication (ECOC 2017) (2017) M.1.E.2.

21) Y. Jung, S. Alam, Y. Sasaki, and D. J. Richardson: Proc. European Conference on Optical Communication (ECOC 2016) (2016) W2B.4.

22) A. Sahara, H. Kawahara, S. Yamamoto, S. Kawai, M. Fukutoku, T. Mizuno, Y. Miyamoto, K. Suzuki, and K. Yamaguchi: Opt. Express 25 (2017) p. 4061. 